\title{
Peran dan Strategi Transportasi Laut Terhadap Konektivitas Antarwilayah di Kabupaten Banggai Laut Provinsi Sulawesi Tengah
}

\author{
The Role and Strategy of Sea Transportation Towards Inter-Regional Connectivity in Banggai Laut \\ Regency Province Center of Sulawesi
}

\author{
Anwar Rappe Sappe ${ }^{1}$, Murshal Manaf ${ }^{2}$, Syafri $^{2}$ \\ ${ }^{1}$ Mahasiswa Program Studi Perencanaan Wilayah dan Kota Program Pascasarjana Universitas Bosowa \\ ${ }^{2}$ Program Studi Perencanaan Wilayah dan Kota Program Pascasarjana Universitas Bosowa \\ E-mail: anwar.rappe@gmail.com \\ Diterima 10 September 2019/Disetujui 4 Desember 2019
}

\begin{abstract}
Abstrak. Tujuan penelitan ini adalah mengetahui peranan transportasi laut terhadap konektivitas antarwilayah di Kabupaten Banggai Laut yang dianalisis menggunakan metode indeks konektivitas dan Merumuskan strategi pengembangan transportasi laut dalam mendukung konektivitas antarwilayah di Kabupaten Banggai Laut dengan menggunakan analisis SWOT. Variabel independen yang digunakan yaitu sistem kegiatan, sistem jaringan, sistem pergerakan, dan sistem kelembagaan dengan variabel dependen adalah peran transportasi. Hasil penelitian menunjukkan bahwa tingkat konektivitas antarwilayah di Kabupaten Banggai Laut terdiri dari tiga klasifikasi yaitu tingkat konektivitas yang tinggi terjadi di Pulau Bokan, karena terdapat tiga titik pelayaran dari Pulau Bokan yang menuju ke satu titik tujuan. Tingkat konektivitas yang sedang terjadi di Pulau Banggai dan Pulau Bangkurung, karena terdapat enam titik pelayaran dari Pulau Banggai yang menuju ke tiga titik tujuan serta dua titik pelayaran dari Pulau Bangkurung yang menuju ke satu titik tujuan. Sedangkan tingkat konektivitas yang rendah terjadi di Pulau Labobo, sebab hanya terdapat satu titik pelayaran dari Pulau Labobo yang menuju ke satu titik tujuan. Strategi-strategi yang dirumuskan untuk pengembangan transportasi laut antara lain menarik investasi swasta dan menggunakan kewenangan daerah untuk mendorong pemerintah provinsi, pusat, maupaun swasta dalam membangun sarana-prasarana transportasi laut lokal, mengembangkan jaringan/rute pelayaran, mengatasi konflik tata ruang dan transparansi pengelolaan anggaran, serta meningkatkan fasilitas dan peralatan keselamatan pelayaran.
\end{abstract}

Kata Kunci: Strategi Transportasi, Konektivitas, SWOT

\begin{abstract}
Abstact. The objective of this research is to determine the role of sea transportation in inter-regional connectivity in Banggai Laut Regency, which was analyzed using the connectivity index method and to formulate a strategy for developing sea transportation in supporting inter-regional connectivity in Banggai Laut Regency using SWOT analysis. The independent variable used is the activity system, network system, movement system, and institutional system with the dependent variable being the role of transportation. The results showed that the level of inter-regional connectivity in Banggai Laut Regency consisted of three classifications: a high level of connectivity occurred on Bokan Island, because there were three shipping points from Bokan Island that went to one destination point. The level of connectivity that is happening on Banggai Island and Bangkurung Island, because there are six shipping points from Banggai Island that go to three destination points and two shipping points from Bangkurung Island that go to one destination point. While the low level of connectivity occurs on Labobo Island, because there is only one shipping point from Labobo Island that goes to one destination point. The strategies formulated for the development of sea transportation include attracting private investment and using regional authority to encourage provincial, central, and private governments in building local sea transportation infrastructure, developing shipping networks / routes, overcoming spatial conflicts and transparency in budget management and improving shipping safety facilities and equipment.
\end{abstract}

Keywords: Transportation Strategy, Conectivity, SWOT

\section{PENDAHULUAN}

Interkoneksi spasial antar pulau-pulau dalam dan di luar gugus pulau dapat berbentuk aktivitas transportasi hasil wilayah dan kebutuhan masyarakat dalam bentuk barang. Perencanaan sistem transportasi kepulauan yang efisien, hendaknya bertolak dari dimensi pengembangan wilayah gugus pulau, yaitu wilayah kepulauan atau gugus pulau yang terdiri atas himpunan pulau-pulau yang relatif besar dan pulau-pulau kecil.
Hambatan pengembangan gugus pulau atau penduduk relatif kecil dan tersebar pada pulau-pulau di sejumlah pulau. Kondisi geografis, demografis dan transportasi laut terbatas. Transportasi sangat penting peranannya bagi daerah baik itu perdesaan atau daerah semi urban atau urban di negara-negara yang sedang berkembang, karena menyediakan akses bagi masyarakat untuk memenuhi kebutuhan barang dan jasa seharihari, serta meningkatkan kehidupan sosial ekonomi. Akses 


\section{Peran dan Strategi Transportasi Laut Terhadap Konektivitas Antarwilayah di Kabupaten Banggai Laut Provinsi Sulawesi Tengah \\ (Anwar Rappe Sappe, Murshal Manaf, Syafri)}

terhadap informasi, pasar, dan jasa masyarakat dan lokasi tertentu, serta peluang-peluang baru kesemuanya merupakan kebutuhan yang penting dalam proses pembangunan. Dengan dibangunnya sarana transportasi, kegiatan ekonomi masyarakat, pemberdayaan masyarakat, khususnya dalam pembangunan pada kawasan yang mempunyai potensi ekonomi tinggi akan lebih mudah dikembangkan. Kegiatan ekonomi masyarakat ini akan berkembang apabila mempunyai prasarana dan sarana transportasi yang baik untuk aksesibilitas. Aksesibilitas ini dapat memacu proses interaksi antar wilayah sampai ke daerah yang paling terpencil sehingga tercipta pemerataan pembangunan.

Menurut Morlock (1988), akibat adanya perbedaan tingkat pemilikan sumberdaya dan keterbatasan kemampuan wilayah dalam mendukung kebutuhan penduduk suatu wilayah menyebabkan terjadinya pertukaran barang, orang dan jasa antar wilayah. Pertukaran ini diawali dengan proses penawaran dan permintaan. Sebagai alat bantu proses penawaran dan permintaan yang perlu dihantarkan menuju wilayah lain diperlukan sarana transportasi. Sarana transportasi yang memungkinkan untuk membantu mobilitas berupa angkutan umum.

Hurst (1974), dikutip oleh Armin Atmajaya (2011) mengemukakan bahwa interaksi antar wilayah tercermin pada keadaan fasilitas transportasi serta aliran orang, barang, maupun jasa. Transportasi merupakan tolok ukur dalam interaksi keruangan antar wilayah dan sangat penting peranannya dalam menunjang proses perkembangan suatu wilayah. Wilayah dengan kondisi geografis yang beragam memerlukan keterpaduan antar jenis transportasi dalam melayani kebutuhan masyarakat. Pada dasarnya sistem transportasi dikembangkan untuk menghubungkan dua lokasi guna lahan yang mungkin berbeda. Transportasi digunakan untuk memindahkan orang atau barang dari satu tempat ke tempat lain sehingga mempunyai nilai ekonomi yang lebih meningkat.

Kabupaten Banggai Laut merupakan kabupaten bahari dengan luas laut sekitar $6.671,32 \mathrm{~km}^{2}$ atau sekitar $72,83 \%$ dari luas keseluruhan. Terdiri dari beberapa pulau, yang saling berhubungan dalam kegiatan sosial, ekonomi dan pemerintahan. Ada 7 kecamatan yang tersebar di empat (4) pulau inti, masing-masing terdapat empat (4) kecamatan di Pulau Banggai sebagai pulau terbesar dan tiga (3) kecamatan masing-masing berada pada Pulau Bangkurung (Kec. Bangkurung), Pulau Labobo (Kec. Labobo) dan Pulau Bokan (Kec. Bokan). (Sumber : Kabupaten Banggai Laut dalam Angka, Tahun 2018). Terbatasnya moda transportasi laut yang menghubungkan empat (4) pulau besar yang ada di Kabupaten Banggai Laut sangat mempengaruhi pola aktifitas masyarakat secara ekonomi dan sosial serta lambatnya proses pembangunan pada wilayah tersebut. Selain itu, belum tersedianya pelabuhan penyeberangan antardaerah di Kabupaten Banggai Laut juga mempengaruhi mobilitas sosial ekonomi masyarakat.

Pengembangan wilayah Kabupaten Banggai Laut cenderung melambat. Hal terlihat dari pertumbuhan (growth) ekonomi Kabupaten Banggai Laut yang selama lima (5) tahun terakhir malah mengalami penurunan (degradasi). BPS Kabu- paten Banggai Laut mencatat PDRB per kapita di Kabupaten Banggai Laut periode 2012 adalah 1.782 .050 (juta/kapita) dan mengalami kenaikan di tahun 2013 menjadi 1.880 .125 (juta/kapita), atau mengalami pertumbuhan 5,50\% dari tahun sebelumnya. Selanjutnya mengalami pertumbuhan yang cukup di tahun 2013 yaitu 0,63\% atau mengalami kenaikan Rp. 98.075,- menjadi Rp.1.880.125,- di tahun 2013. Di periode tahun 2016 ada pertumbuhan $0,75 \%$ dari tahun sebelumnya yaitu Rp.1.910.900,-. Hal ini menunjukan ada Pengembangan Wilayah, meskipun cenderung lambat, dikarenakan pertumbuhan dibawah $1 \%$.

Pertumbuhan wilayah yang cenderung melambat ini diduga merupakan dampak dari interaksi keruangan dan mobilisasi /distribusi barang yang cenderung melemah, hal tersebut didukung oleh pendapat (Kansky, 1963 dalam Fithra, 2017) dengan teorinya yang menyatakan bahwa kekuatan interaksi ditentukan dengan Indeks Konektivitas. Semakin tinggi nilai indeks, semakin banyak jaringan jalan yang menghubungkan kota-kota atau wilayah yang sedang dikaji. Hal ini tentunya berpengaruh terhadap potensi pergerakan manusia, barang, dan jasa karena prasarana jalan sangat memperlancar tingkat mobilitas antarwilayah.

Hasil penelitian ini bisa menjadi salah satu rujukan atau bahan pertimbangan bagi pemerintah daerah dalam merumuskan konsep perencanaan wilayah dan kota di Kabupaten Banggai Laut, lebih khususnya strategi pengembangan konektivitas transportasi laut antarwilayah yang mendukung pertumbuhan perekonomian di kabupaten dan kecamatan yang ada di Kabupaten Banggai Laut. Dengan pertimbangan yang telah diuraikan di atas, maka dirumuskanlah pertanyaan penelitian sebagai berikut: (1) Bagaimana peran transportasi laut terhadap konektivitas antarwilayah di Kabupaten Banggai Laut; dan (2) Bagaimana strategi pengembangan transportasi laut dalam mendukung konektivitas antarwilayah di Kabupaten Banggai Laut. Tujuan yang ingin dicapai pada penelitian ini adalah : (1) Menganalisis peran transportasi laut terhadap konektivitas antarwilayah di Kabupaten Banggai Laut; (2) Merumuskan strategi pengembangan transportasi laut dalam mendukung konektivitas antar wilayah di Kabupaten Banggai Laut.

Berdasarkan latar belakang teori diatas, maka dapat diajukan sebuah hipotesa penelitian dengan pernyataan sebagai berikut: "Konektivitas transportasi laut antarwilayah yang paling tinggi terjadi di Pulau Banggai".

\section{METODE PENELITIAN}

Penelitian ini menggunakan pendekatan deskriptif kuantitatif, melalui uji secara matematis menggunakan metode Indeks Konektivitas untuk mengetahui peranan transportasi laut terhadap konektivitas antarwilayah di Kabupaten Banggai Laut berdasarkan variabel dan indikator yang telah di tentukan. Metode yang digunakan dalam penelitian ini adalah metode observasi berupa survey dan pengamatan langsung di lokasi penelitian, dengan mengumpulkan informasi yang berkaitan dengan objek dan subjek yang diteliti, serta pengambilan data- 
data pendukung pada instansi terkait lainnya. Proses analisis yang terakhir yaitu merumuskan strategi pengembangan transportasi dalam mendukung pengembangan wilayah di Kabupaten Banggai Laut dengan menggunakan rangkaian analisis SWOT.

Penelitian ini berlokasi di Kabupaten Banggai Laut yang terdiri dari 7 (tujuh) Kecamatan dan berada pada 4 (empat) pulau utama yang ada di Propinsi Sulawesi Tengah. Dengan pertimbangan terdapat interaksi antar empat pulau yang saling berkoneksi yakni Pulau Banggai, Pulau Bangkurung, Pulau Labobo, dan Pulau Bokan.

Tabel 1. Variabel dan Indikator Penelitian

\begin{tabular}{|c|c|c|}
\hline No. & Variabel & Indikator \\
\hline 1. & Peran Transportasi (Y) & - $\quad$ Konektivitas \\
\hline 2. & Sistem Kegiatan $\left(\mathrm{X}_{1}\right)$ & $\begin{array}{l}\text { - Pola penggunaan lahan } \\
\text { kegiatan sosial } \\
\text { - Pola penggunaan lahan } \\
\text { kegiatan ekonomi }\end{array}$ \\
\hline 3. & Sistem Jaringan $\left(\mathrm{X}_{2}\right)$ & $\begin{array}{ll}\text { - } & \text { Sarana dan prasarana } \\
\text { transportasi laut } \\
\text { - } \quad \text { Trayek moda transportasi }\end{array}$ \\
\hline 4. & Sistem Pergerakan $\left(\mathrm{X}_{3}\right)$ & $\begin{array}{ll}\text { - } & \text { Pola pergerakan orang } \\
\text { - } & \text { Pola pergerakan barang } \\
\text { - } & \text { Waktu tempuh } \\
\text { - } & \text { Tarif angkutan } \\
\end{array}$ \\
\hline 5. & Sistem Kelembagaan $\left(\mathrm{X}_{4}\right)$ & - $\quad$ Kebijakan transportasi \\
\hline
\end{tabular}

Sumber : Hasil Pengolahan, Tahun 2019

Populasi yang digunakan dalam penelitian ini mengacu dari data Badan Pusat Statistik, berupa total jumlah di Kabupaten Banggai Laut. Berdasarkan data yang diperoleh didapatkan lokasi penelitian dengan populasi sebanyak 70.886 jiwa.

Teknik penarikan sampel dalam penelitian menggunakany metode purposive sampling yang dikenal dengan sampling pertimbangan yaitu sampling yang digunakan jika peneliti mempunyai pertimbangan-pertimbangan tertentu didalam pengambilan sampelnya atau penentuan sampel untuk tujuan tertentu, dengan menggunakan rumus dari Taro Yamane Dalam Akdon dan Riduwan (2007:44):

$$
n=\frac{\mathrm{N}}{\mathrm{N}(\mathrm{d})^{2}+1}
$$

Dimana :

$$
\begin{array}{ll}
n & =\text { Jumlah Sampel } \\
N & =\text { Jumlah jiwa di setiap lokasi penelitian } . \\
d & =\text { Derajat yang ditetapkan }(0,05)
\end{array}
$$

Berdasarkan rumus diatas, maka sampel yang digunakan pada penelitian ini dapat dihitung sebagai berikut :

$$
\begin{aligned}
& n=\frac{70.886}{70.886(0,05)^{2}+1} \\
& n=397,76 \approx 398 \text { jiwa }
\end{aligned}
$$

Total sampel untuk penyebaran kuesioner berdasarkan hasil perhitungan adalah 398 jiwa.
Metode pengumpulan data yang digunakan untuk lebih mempermudah dalam melakukan ini adalah : (1) Observasi lapangan adalah penelitian yang dilakukan dengan cara survei langsung kelapangan untuk memperoleh data yang terkait dengan penelitian ini. Menggunakan alat-alat instrumen seperti wawancara terbuka (open interview), daftar pertanyaan (questionnaires), dan pengambilan gambar (visualisasi). (2) Pendataan instansional, mengumpulkan data melalui instansi terkait baik itu data kuantitatif dan kualitatif obyek penelitian. (3) Telaah pustaka, peneliti mempelajari data, baik data kualitatif maupun data kuantitatif melalui sumber dokumen (Laporan, Monografi Daerah, Buku-buku, Artikel Ilmiah, dan lainnya).

Analisis Indeks Konektivitas digunakan untuk menganalisis peranan transportasi laut terhadap konektivitas antarwilayah di Kabupaten Banggai Laut. Menurut Kansky dalam Fithra, (2017), kekuatan interaksi ditentukan dengan Indeks Konektivitas. Semakin tinggi nilai indeks, semakin banyak jaringan jalan yang menghubungkan kota-kota atau wilayah yang sedang dikaji. Hal ini tentunya berpengaruh terhadap potensi pergerakan manusia, barang, dan jasa karena prasarana jalan sangat memperlancar tingkat mobilitas antarwilayah. Untuk meng-hitung indeks konektivitas ini digunakan rumus (Kansky, 1963) berikut :

$$
\beta=\frac{\mathrm{e}}{\mathrm{v}}
$$

Keterangan:

$B=$ Indeks Konektivitas

$e=$ Jumlah Rute Pelayaran

$v=$ Jumlah Pulau

Menganalisis strategi pengembangan transportasi laut dalam mendukung konektivitas antarwilayah di Kabupaten Banggai Laut, maka digunakan 3 metode analisis yaitu analisis EFE-IFE, analisis SWOT dan analisis QSPM. Menurut David (2017) dapat dilakukan melalui tiga tahap analisis yakni Tahap Input (Input Stage), Tahap Pencocokan (Matching Stage) dan Tahap Keputusan (Decision Stage).

\begin{tabular}{|c|}
\hline Tahap I (Tahap Input) \\
Matriks Evaluasi Faktor Eksternal (EFE) Matriks \\
Evaluasi Faktor Interrnal (IFE) \\
\hline Tahap II (Tahap Pencocokan) \\
Matriks Kekuatan - Kelemahan - Peluang - Tantangan \\
(SWOT) \\
\hline Tahap III ( Tahap Keputusan) \\
Matriks Perencanaan Strategis kuantitatif \\
(QSPM)
\end{tabular}

Gambar 1. Kerangka Analisis Perumusan Strategi

1. Tahap Input (Input Stage)

Dalam melakukan penyusunan strategi dan perancangan program tahap I diawali dengan membuat analisis Internal Factor Evaluation (IFE) dan External Factor Evaluation (EFE). Matriks IFE digunakan untuk meringkas dan mengevaluasi kekuatan dan kelemahan utama, sedangkan 


\section{Peran dan Strategi Transportasi Laut Terhadap Konektivitas Antarwilayah di Kabupaten Banggai Laut Provinsi Sulawesi Tengah \\ (Anwar Rappe Sappe, Murshal Manaf, Syafri)}

matriks EFE digunakan untuk pengambilan keputusan dalam meringkas dan mengevaluasi semua informasi lingkungan eksternal meliputi peluang dan ancaman.

\section{Tahap Pencocokan (Matching Stage)}

Hasil analisis faktor internal dan eksternal dilanjutkan dengan Tahapan Pencocokan dengan menggunakan analisis SWOT (Strenght, Weakness, Opportunity, Threat). Analisis ini merupakan alat untuk memaksimalkan peranan faktor yang bersifat positif, meminimalisasi kelemahan yang ada serta menekan dampak ancaman yang timbul.Hasil Analisis SWOT adalah berupa sebuah matriks dengan empat kuadran yang merupakan perpaduan strategi antara faktor internal (kekuatan dan kelemahan) dan faktor eksternal (peluang dan ancaman).

Tabel 2. Matriks SWOT

\begin{tabular}{|c|c|c|}
\hline$\underbrace{\text { INTERNAL }}_{\text {EKSTERNAL }}$ & $\begin{array}{l}\text { STRENGTHS } \\
\text { (S) }\end{array}$ & $\begin{array}{c}\text { WEAKNESSES } \\
(\mathrm{W})\end{array}$ \\
\hline $\begin{array}{c}\text { OPPRTUNITES } \\
(\mathbf{O})\end{array}$ & $\begin{array}{l}\text { STRATEGI (S-O) } \\
\text { Menggunakan } \\
\text { kekuatan untuk } \\
\text { memanfaatkan } \\
\text { peluang }\end{array}$ & \begin{tabular}{l} 
STRATEGI (W- \\
\multicolumn{1}{c}{ O) } \\
Meminimalkan \\
kelemahan untuk \\
memanfaatkan \\
peluang
\end{tabular} \\
\hline THREATS (T) & $\begin{array}{l}\text { Strategi (S-T) } \\
\text { Menggunakan } \\
\text { kekuatan untuk } \\
\text { mengatasi } \\
\text { ancaman }\end{array}$ & $\begin{array}{l}\text { Strategi (W-T) } \\
\text { Minimalkan } \\
\text { kelemahan dan } \\
\text { menghindari } \\
\text { ancaman }\end{array}$ \\
\hline
\end{tabular}

Sumber : David, (2017)

\section{Tahap Keputusan (Decision Stage)}

Dalam melakukan perumusan strategi dan perancangan program digunakan Quantitative Strategic Planning Matrix (QSPM). Metode ini merupakan alat untuk mengevaluasi strategi alternative secara objektif berdasarkan pada faktor faktor kunci internal dan eksternal.

Analisis QSPM juga merupakan teknik yang digunakan pada tahap pengambilan keputusan karena menunjukan strategi alternative yang paling baik dipilih. Pada matriks QSPM terdapat komponen - komponen utama yang terdiri dari Key Factors, Strategic Alternatives, Weights, Attractiveness Score, Total Attractivess Score dan Sum Total Attractivess Score.

\section{HASIL DAN PEMBAHASAN}

\section{Peran Transportasi Laut Terhadap Konektivitas Antarwilayah}

Sebelum melakukan analisis tingkat konektivitas, perlu diketahui jumlah jalur transportasi serta jumlah titik/pulau yang dilayani. Data tersebut disajikan dalam tabel 3. dengan menggunakan rumus indeks konektivitas, maka hasil perhitungan indeks konektivitas dapat diihat pada tabel 4 yang disajikan dibawah ini.
Tabel 3. Rute dan Titik Tujuan Transportasi Laut di Kabupaten Banggai Laut Tahun 2017

\begin{tabular}{llcc}
\hline No & \multicolumn{1}{c}{ Pulau } & $\begin{array}{c}\text { Jalur } \\
\text { Pelayaran }\end{array}$ & $\begin{array}{c}\text { Titik/Pulau } \\
\text { Tujuan }\end{array}$ \\
\hline 1. & Banggai & 6 & 3 \\
2. & Labobo & 1 & 1 \\
3. & Bangkurung & 2 & 1 \\
4. & Bokan & 3 & 1 \\
\hline
\end{tabular}

Sumber: Dinas Perhubungan Kabupaten Banggai Laut,

Tahun 2019

Tabel 4. Nilai Indeks dan Tingkat Konektivitas Antarwilayah di Kabupaten Banggai Laut Tahun 2017

\begin{tabular}{llcc}
\hline No & \multicolumn{1}{c}{ Pulau } & $\begin{array}{c}\text { Nilai } \\
\text { Indeks }\end{array}$ & $\begin{array}{c}\text { Tingkat } \\
\text { Konektivitas }\end{array}$ \\
\hline $\mathbf{1 .}$ & Banggai & 2 & Sedang \\
$\mathbf{2 .}$ & Labobo & 1 & Rendah \\
$\mathbf{3 .}$ & Bangkurung & 2 & Sedang \\
$\mathbf{4 .}$ & Bokan & 3 & Tinggi \\
\hline
\end{tabular}

Sumber: Hasil Analisi, Tahun 2019

Berdasarkan hasil analisis indeks konektivitas, diketahui bahwa tingkat konektivitas antarwilayah pulau di Kabupaten Banggai Laut terbagi menjadi 3 (tiga) klasifikasi, yaitu Pulau Bokan dengan tingkat konektivitas yang tinggi, Pulau Banggai dan Pulau Labobo dengan tingkat konektivitas sedang, sedangkan Pulau Bangkurung dengan tingkat konektivitas rendah.

Tingginya tingkat konektivitas di Pulau Bokan dipengarui oleh banyaknya jalur pelayaran dan sedikitnya titik tujuan. Dalam hal ini, terdapat tiga jalur pelayaran dari Pulau Bokan yang semuanya menuju ke Pulau Banggai, sehingga konektivitas antarwilayah pulau yakni antara Pulau Bokan dengan Pulau Banggai terbilang tinggi. Tingginya bangkitan lalulintas dari Pulau Bokan menuju ke Pulau Banggai didukung oleh pernyataan responden sebagai pengguna transportasi, yang menyatakan bahwa aksesibilitas transportasi yang terjadi cukup dipengaruhi oleh sistem kegiatan berupa kebutuhan mengakses fasilitas sosial dan ekonomi di Pulau Banggai, seperti akses terhadap layanan kesehatan, pendidikan, pariwisata, perdagangan, maupun jasa perbankan. Selain itu, dipengaruhi pula oleh sistem jaringan, dimana karena didukung oleh ketersediaan sarana dan prasarana transportasi laut yang cukup memadai, juga ketersediaan trayek/rute moda transportasi yang sangat menjawab kebutuhan perjalanan. Sementara kaitannya dengan sistem pergerakan dinilai masih kurang mendukung, dimana aktifitas pergerakan orang dan barang masih cukup rendah, meskipun telah didukung oleh waktu tempuh yang cukup memuaskan dan tarif angkutan yang relatif sangat terjangkau. Selain itu, dukungan pemerintah secara sistem kelembagaan terhadap pembangunan transportasi yang dinilai kurang maksimal menjadi salah satu kelemahan yang harus terus dibenahi.

Tingkat konektivitas yang sedang terjadi di Pulau Banggai dan juga Pulau Bangkurung. Di Pulau Banggai, jumlah jalur pelayaran sangat banyak yang juga diimbangi dengan jumlah titik tujuan yang banyak pula. Yakni jumlah jalur dari Pulau Banggai terdiri dai 6 (enam) jalur dengan titik tujuan berjumlah 
3 titik. Yaitu terdiri dari 1 jalur menuju Pulau Labobo, 2 jalur menuju Pulau Bangkurung, dan 3 jalur menuju Pulau Bokan. Sehingga dipastikan bahwa jalur yang banyak dengan jumlah tujuan yang banyak menyebabkan tingkat konektivitas menjadi tidak terlalu tinggi (sedang) dari daerah asal ke daerah tujuan. Sama halnya dengan Pulau Banggai, di Pulau Bangkurung jumlah jalur terdiri dari 2 jalur, yang keduanya menuju ke 1 titik tjuan yaitu Pulau Banggai. Sehigga dapat dipastikan bahwa tingkat konektivitas yang terjadi antara Pulau Bangkurung dengan Pulau Banggai relatif sedang. Hal ini tentunya sangat dipengaruhi oleh sistem pergerakan, dimana waktu tempuh yang terbilang cukup memuaskan didukung oleh tarif angkutan yang sangat terjangkau, belum memberikan efek positif terhadap peningkatan aktifitas pergerakan orang dan barang. Aktifitas pergerakan orang dan barang yang sangat rendah besar kemungkinan terjadi akibat sistem jaringan berupa ketersediaan sarana dan prasarana serta trayek/rute moda transportasi yang masih sedikit. Selain itu dapat pula dipengaruhi oleh sistem kegiatan, dimana tujuan perjalanan tidak selalu untuk mengakses fasilitas sosial dan ekonomi yang ada. Dukungan pemerintah daerah berupa sistem kelembagaan yang masih kurang juga menjadi faktor pendukung yang menyebabkan konektivitas Pulau Banggai dan Pulau Bangkurung terklasifikasi sedang.

Sedangkan tingkat konektivitas yang rendah terjadi di Pulau Labobo, dimana hanya memiliki 1 jalur yang menuju ke 1 titik tujuan yaitu Pulau Banggai. Sehingga dapat dipastikan bahwa tingkat konektivitas antara pulau Labobo dengan Pulau Banggai relatif lemah. Sistem kelembagaan sebagai faktor pengontor berperan penting terhadap lemahnya konektivitas yang terjadi di Pulau Bokan. Dimana dukungan pemerintah berupa kebijakan-kebijakan terkait peningkatan peran transportasi laut belum cukup maksimal. Selain itu, dukungan sistem jaringan berupa ketersediaan sarana dan prasarana transportasi perlu ditingkatkan dengan tetap memaksimalkan trayek/rute moda transportasi yang sudah sangat memadai. Apabila dihubungkan dengan sistem pergerakan, terlihat bahwa tarif angkutan yang terjangkau didukung oleh waktu tempuh yang cukup memuaskan tidak memberikan pengaruh besar terhadap meningkatnya pergerakan orang dan barang. Hal tersebut terjadi dimungkinkan karena sistem kegiatan yang terjadi belum cukup berdampak ada bangkitan-tarikan lalulintas dari Pulau Bokan menuju ke Pulau Banggai.

Berdasarkan data, pulau-pulau di Kabupaten Banggai Laut yang tidak memiliki konektivitas transportasi adalah antara Pulau Labobo dengan Pulau Bangkurung, Pulau Labobo dengan Pulau Bokan, serta antara Pulau Bokan dengan Pulau Bangkurung. Oleh sebab itu, pulau-pulau di Kabupaten Banggai Laut yang belum memiliki konektivitas ataupun tingkat konektivitas yang masih rendah perlu untuk dirumuskan strategi-strategi alternatif dalam meningkatkan Konektivitas antarwilayah tersebut.

\section{Strategi Pengembangan Transportasi Laut Dalam Mendukung Konektivitas Antarwilayah}

\section{Identifikasi Faktor Internal dan Eksternal}

Dari hasil pengamatan dan wawancara dengan sejumlah responden di lapangan diperoleh beberapa faktor strategis yang sangat berpengaruh terhadap pengembangan transportasi laut antar pulau di Kabupaten Banggai Laut. Faktor strategis tersebut terdiri dari faktor internal yang meliputi kekuatan dan kelemahan, serta faktor eksternal yang meliputi peluang dan ancaman (Tabel 5).

Data yang diperoleh dari Tabel 5 digunakan untuk perhitungan Matrik Space Analysis, maka diketahui skala penilaian sebagai berikut :
a. Skor Kekuatan : $+1,795$
b. Skor Kelemahan : $-1,543$
c. Skor Peluang : $+1,828$
d. Skor Ancaman : $-1,693$

Sehingga untuk dapat membuat titik koordinat horisontal pada gambar skala penilaian yaitu dengan menjumlahkan nilai kekuatan dengan nilai kelemahan. Maka dapat diperoleh titik koordinat horizontal, yaitu: $(+1,795)+(-1,543)=+0,252$

Sedangkan untuk membuat titik koordinat vertical pada gambar skala penilaian yaitu dengan menjumlahkan nilai peluang perusahaan dengan nilai ancaman perusahaan. Maka diperoleh titik koordinat vertikal, yaitu: $(+1,828)+(-1,693)=+$ 0,135 .

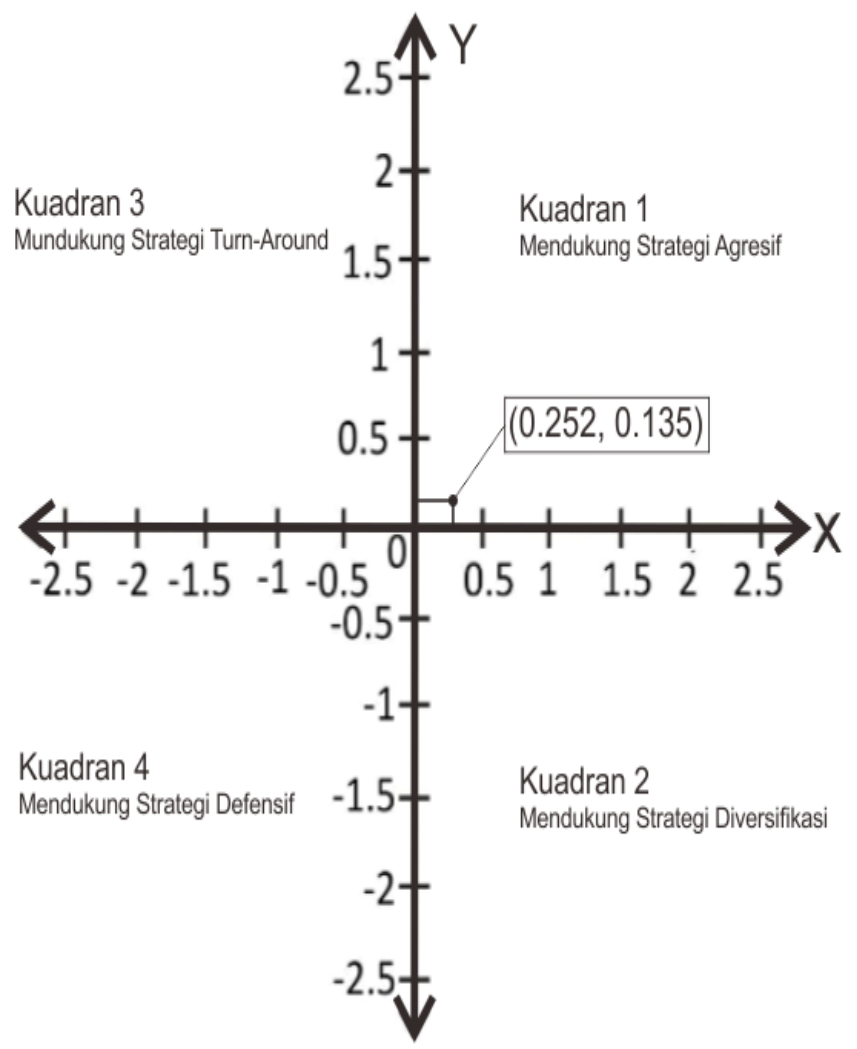

Gambar 2. Diagram Kuadran Analisis SWOT 
Tabel 5. Matriks IFAS dari Strategi Pengembangan Transportasi Laut dalam Mendukung Konektivitas Antarwilayah di Kabupaten Banggai Laut

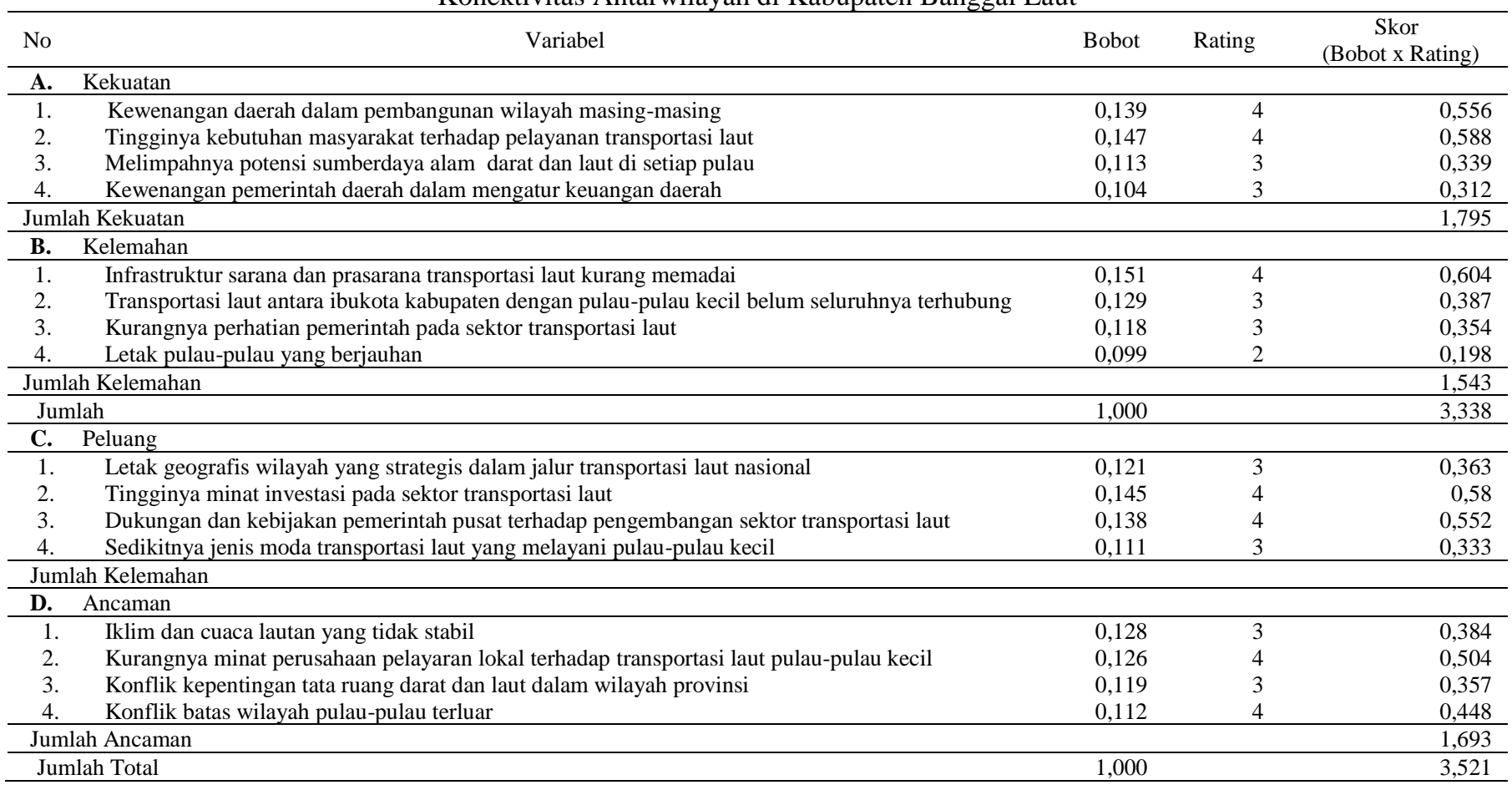

Tahap selanjutnya adalah tahap penggabungan (matching stage) dengan teknis matriks Strengths - Weaknesses Opportunities - Threats (SWOT) atau kekuatan - kelemahan peluang-ancaman. Analisis SWOT ini didasarkan pada informasi yang diturunkan dari tahap input untuk mencocokan kekuatan dan kelemahan internal dengan peluang dan ancaman eksternal.

Tabel 6. Matrix SWOT

\begin{tabular}{|c|c|c|}
\hline FAKTOR EKSTERNAL & 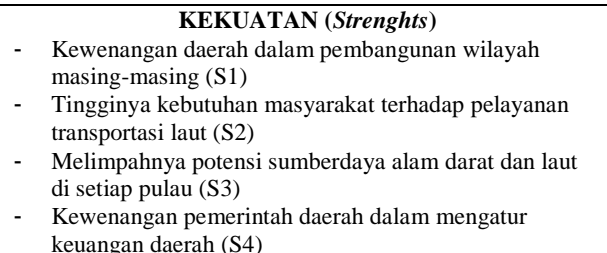 & \begin{tabular}{ll}
\multicolumn{1}{c}{ KELEMAHAN (Weaknesses) } \\
- & Infrastruktur sarana dan prasarana transportasi laut kurang \\
memadai (W1) \\
-
\end{tabular} \\
\hline $\begin{array}{ll}\text { PELUANG (Opportunities) } \\
-\quad & \text { Letak geografis wilayah yang strategis } \\
\text { dalam jalur transportasi laut nasional }(\mathrm{O} 1) \\
-\quad & \text { Tingginya minat investasi pada sektor } \\
& \text { transportasi laut }(\mathrm{O} 2) \\
-\quad & \text { Dukungan dan kebijakan pemerintah pusat } \\
& \text { terhadap pengembangan sektor } \\
& \text { transportasi laut }(\mathrm{O} 3) \\
- & \text { Sedikitnya jenis moda transportasi laut } \\
& \text { yang melayani pulau-pulau kecil }(\mathrm{O} 4)\end{array}$ & \begin{tabular}{ll}
\multicolumn{1}{c}{ STRATEGI S-O } \\
- & \multicolumn{1}{c}{ Menggunakan kewenangan daerah untuk menambah } \\
moda transportasi dalam memenuhi kebutuhan \\
pelayanan transportasi $(\mathrm{S} 1, \mathrm{~S} 2, \mathrm{~S} 4, \mathrm{O} 2, \mathrm{O} 4)$ \\
- & Mengatur keuangan daerah dengan memanfaatkan \\
investasi sektor transportasi laut dalam menyedikan \\
moda transportasi (S1, S4, O2, O4) \\
- Memanfaatkan dukungan pemerintah dan jalur \\
trasportasi laut nasional untuk memenuhi kebutuhan \\
transportasi serta mendistribusikan hasil sumber daya \\
alam (S1, S2, S3, O1, O3)
\end{tabular} & \begin{tabular}{ll}
\multicolumn{1}{c}{ STRATEGI W-O } \\
Menambah sarana dan prasarana serta rute transportasi \\
laut untuk meningkatkan pelayanan transportasi pada \\
pulau-pulau kecil (W1, W2, W4, O4) \\
$-\quad$ Mendorong kebijakan pemerintah pusat untuk \\
meningkatkan penganggaran pembangunan transportasi \\
antarpulau (W1, W2, W3, W4, O3, O4) \\
- & Memanfaatkan dukungan pemerintah pusat dan jalur \\
transportasi laut nasional untuk meningkatkan layanan \\
transportasi dan meminimalisir anggaran pembangunan \\
transportasi antar kabupaten $(\mathrm{W} 1, \mathrm{~W} 3, \mathrm{O}, \mathrm{O}$ ) 3 )
\end{tabular} \\
\hline $\begin{array}{l}\text { ANCAMAN (Threats) } \\
-\quad \text { Iklim dan cuaca lautan yang tidak stabil } \\
\text { (T1) } \\
\text { Kurangnya minat perusahaan pelayaran } \\
\text { lokal terhadap transportasi laut pulau- } \\
\text { pulau kecil (T2) } \\
\text { Konflik kepentingan tata ruang darat dan } \\
\text { laut dalam wilayah provinsi (T3) } \\
\text { - Konflik batas wilayah pulau-pulau terluar } \\
\text { (T4) }\end{array}$ & $\begin{array}{l}\text { STRATEGI S-T } \\
\text { Menggunakan kewenangan daerah dalam mengelola } \\
\text { sumber daya alam dan memanfaatkan tingginya } \\
\text { kebutuhan transportasi untuk meningkatkan minat } \\
\text { swasta dalam membangun transportasi lokal (S1, S2, } \\
\text { S3, S4, T2) } \\
\text { Menggunakan kewenangan daerah untuk mengatasi } \\
\text { konflik tata ruang dan konflik batas wilayah pulau } \\
\text { terluar (S1, S4, T3, T4) } \\
\text { Menggunakan kewenangan daerah untuk meningkatkan } \\
\text { fasilitas dan peralatan keselamatan pelayaran (S1, S4, } \\
\text { T1) }\end{array}$ & $\begin{array}{l}\text { STRATEGI W-T } \\
\text { Mendorong peran serta pemerintah provinsi, pusat, dan } \\
\text { sektor swasta untuk membangun transportasi di daerah } \\
\text { kepulauan (W1, W2, W3, W4, T2, T3) } \\
\text { - Meningkatkan penganggaran dan transparansi } \\
\text { pengelolaannya dalam membangun sarana-prasarana } \\
\text { transportasi laut untuk menghubungkan pulau-pulau kecil } \\
\text { yang berjauhan (W1, W2, W3, W4, T2, T4) } \\
\text { - Meningkatkan penganggaran pembangunan sarana dan } \\
\text { prasarana mendukung keselamatan pelayaran (W1, W3, } \\
\text { T1) }\end{array}$ \\
\hline
\end{tabular}


Tabel 7. Hasil Analisis QSPM

\begin{tabular}{|c|c|c|c|}
\hline No & Alternatif Strategi & Nilai TAS & Prioritas \\
\hline 1. & $\begin{array}{l}\text { Menggunakan kewenangan daerah untuk menambah moda transportasi dalam memenuhi kebutuhan } \\
\text { pelayanan transportasi }\end{array}$ & 5,768 & 10 \\
\hline 2. & $\begin{array}{l}\text { Mengatur keuangan daerah dengan memanfaatkan investasi sektor transportasi laut dalam menyedikan } \\
\text { moda transportasi }\end{array}$ & 6,551 & 3 \\
\hline 3. & $\begin{array}{l}\text { Memanfaatkan dukungan pemerintah dan jalur trasportasi laut nasional untuk memenuhi kebutuhan } \\
\text { transportasi serta mendistribusikan hasil sumber daya alam }\end{array}$ & 6,047 & 8 \\
\hline 4. & $\begin{array}{l}\text { Menggunakan kewenangan daerah dalam mengelola sumber daya alam dan memanfaatkan tingginya } \\
\text { kebutuhan transportasi untuk meningkatkan minat swasta dalam membangun transportasi lokal }\end{array}$ & 6,715 & 1 \\
\hline 5. & $\begin{array}{l}\text { Menggunakan kewenangan daerah untuk mengatasi konflik tata ruang dan konflik batas wilayah pulau } \\
\text { terluar }\end{array}$ & 5,261 & 11 \\
\hline 6. & Menggunakan kewenangan daerah untuk meningkatkan fasilitas dan peralatan keselamatan pelayaran & 5,179 & 12 \\
\hline 7. & $\begin{array}{l}\text { Menambah sarana dan prasarana serta rute transportasi laut untuk meningkatkan pelayanan transportasi } \\
\text { pada pulau-pulau kecil }\end{array}$ & 6,172 & 6 \\
\hline 8. & $\begin{array}{l}\text { Mendorong kebijakan pemerintah pusat untuk meningkatkan penganggaran pembangunan transportasi } \\
\text { antarpulau }\end{array}$ & 6,348 & 4 \\
\hline 9. & $\begin{array}{l}\text { Memanfaatkan dukungan pemerintah pusat dan jalur transportasi laut nasional untuk meningkatkan } \\
\text { layanan transportasi dan meminimalisir anggaran pembangunan transportasi antar kabupaten }\end{array}$ & 6,046 & 9 \\
\hline 10. & $\begin{array}{l}\text { Mendorong peran serta pemerintah provinsi, pusat, dan sektor swasta untuk membangun transportasi di } \\
\text { daerah kepulauan }\end{array}$ & 6,582 & 2 \\
\hline 11. & $\begin{array}{l}\text { Meningkatkan penganggaran dan transparansi pengelolaannya dalam membangun sarana-prasarana } \\
\text { transportasi laut untuk menghubungkan pulau-pulau kecil yang berjauhan }\end{array}$ & 6,275 & 5 \\
\hline 12. & Meningkatkan penganggaran pembangunan sarana dan prasarana mendukung keselamatan pelayaran & 6,135 & 7 \\
\hline
\end{tabular}

Sumber : Hasil Analisi, Tahun 2019

Tahap selanjutnya dari perumusan strategi adalah tahap pengambilan keputusan dengan menggunakan analisis QSPM (Quantitative Strategic Planning Matrix). Analisis ini ditujukan untuk menentukan prioritas strategi pengembangan transportasi laut dalam mendukung konektivitas antar pulau di Kabupaten Banggai Laut.

\section{KESIMPULAN}

Berdasarkan hasil analisis dan pembahasan yang telah dikemukakan sebelumnya, maka dapat ditarik kesimpulan sebagai bahwa peran transportasi laut terhadap konektivitas antarwilayah ditunjukkan berdasarkan tingkat konektivitasnya, yakni Pulau Bokan dengan tingkat konektivitas tinggi, Pulau Banggai dan Pulau Bangkurung dengan tingkat konektivitas sedang, Serta Pulau Labobo dengan tingkat konektivitas rendah, selanjutnya untuk strategi yang dapat dilakukan untuk meningkatkan konektivitas antarwilayah ialah; (1) Menggunakan kewenangan daerah untuk mendorong pemerintah provinsi, pusat, maupaun swasta dalam membangun transportasi lokal, mengatasi konflik tata ruang dan transparansi, pengelolaan anggaran serta meningkatkan fasilitas dan peralatan keselamatan pelayaran. (2) Mendorong kebijakan pemerintah pusat untuk meningkatkan penganggaran pembangunan sarana-prasarana transportasi antarpulau, serta mengatur keuangan daerah untuk memanfaatkan investasi sektor transportasi laut dalam menyedikan moda transportasi. (3) Memanfaatkan dukungan pemerintah pusat dan jalur transportasi laut nasional untuk meningkatkan layanan transportasi dan meminimalisir anggaran pembangunan transportasi antar kabupaten.

\section{DAFTAR PUSTAKA}

Akdon, Riduwan. (2007). Rumus dan Data Dalam Analisis Statistika. Cetakan Kedua. Alfabeta: Bandung

Atmajaya, Armin. (2011). Pengaruh Perkembangan Transportasi Dalam Pertumbuhan Ekonomi. Jurnal UNM: Makassar

David, Fred R. (2006). Manajemen Strategis. Edisi Sepuluh. Salemba Empat: Jakarta

Fithra, Herman. (2017). Konektivitas Jaringan Jalan Dalam Pengembangan Wilayah Di Zona Utara Aceh. Sefa Bumi Persada: Aceh

Fred, R. David, (2017). Manajemen Strategis Konsep. Salemba Empat: Jakarta

Morlock, Edward K. (1988). Pengantar Teknik dan Perencanaan Transportasi. Erlangga: Jakarta. 